\title{
CEO Compensation and Firm Performance: The Role of ESG Transparency
}

\section{Chetna Rath $^{1 *}$ (1) | Florentina Kurniasari² (D) | Malabika Deo 3}

\author{
${ }^{1}$ Pondicherry University, Department of Commerce, School of Management, India \\ ${ }^{2}$ Universitas Multimedia Nusantara, Technology Management Department, Indonesia \\ ${ }^{3}$ Pondicherry University, Department of Commerce, School of Management, India
}

* Correspondence to: Chetna Rath, Pondicherry University, Department of Commerce, School of Management, India.

E-mail: rathchetna@gmail.com

\begin{abstract}
Chief executive officers (CEOs) of environmental, social, and governance (ESG) firms are known to take lesser pay and engage themselves in corporate social responsibility activities to achieve the dual objective of the enhancement of firm's performance as well as benefit for stakeholders in the long run. This study examines the role of ESG transparency in strengthening the impact of firm performance on total CEO pay in ESG firms. A panel of 67 firms for the period of 2014-2019 has been analyzed using the two-step system GMM model, with NSE Nifty 100 ESG Index as the data sample and ESG scores from Bloomberg database as a proxy for transparency. Findings reveal that environmental and governance disclosure scores have the potential to intensify the negative relationship between firm performance and CEO compensation, while social disclosure scores do not. In addition, various firmspecific, board-specific, and CEO-specific attributes have also been considered controls affecting remuneration. This paper contributes to the literature by exploring the effect of exhibiting ESG transparency and its nexus with CEO pay as well as firm performance.
\end{abstract}

Keywords: CEO compensation, ESG firms, ESG transparency, firm performance, India.

Article info: Received 29 May 2020 | revised 06 August 2020 | accepted 02 November 2020

Recommended citation: Rath, C., Kurniasari, F., Deo, M. (2020). CEO Compensation and Firm Performance: The Role of ESG Transparency. Indonesian Journal of Sustainability Accounting and Management, 4(2), 278-293. https://doi.org/10.28992/ijsam.v4i2.225.

\section{INTRODUCTION}

The cut-throat competition in the contemporary era has tempted the companies to use "social responsibility" dimension as a parameter to outshine as well as sustain in the long run. Environmental, social and governance (ESG) companies are believed to have necessary concern toward the environment and society encompassing us, by formulating the required set of standards for regular operations as well as screening potential avenues for

Copyright $(2020$ by the author(s). This article is published under the Creative Commons Attribution (CC BY 4.0) license. Anyone may reproduce, distribute, translate and create derivative works of this article (for both commercial \& noncommercial purposes), subject to full attribution to the original publication and author(s). The full terms of this license may be seen at http://creativecommons.org/licenses/by/4.o/legalcode. 
investments. These corporations diligently abide to required compliances and follow necessary ethical practices to achieve their long-term competitiveness and growth (Clarkson, 1995). The connotation of "ESG" is rapidly evolving over the years and has garnered increasing attention from various parties, thereby potentially leading financial performance indicators of the companies (Khan, 2019). Especially with the outbreak of coronavirus 2019 (COVID-19) pandemic, responsibility toward ESG is believed to be a wake-up call for decision makers that would have consideration for biodiversity/climate change issues along with traditional financial metrics (J.P. Morgan Research, 2020).

In a country like India where the unemployment rate is quite high and per capita income is low, the compensation ${ }^{1}$ paid to the top-level executives has always been a buzzword leading to a spotlight debate. India's $73 \%$ of the total national wealth being concentrated in the hands of just $1 \%$ of the top-notch industrialists explains the widening income differences prevalent in the country (Oxfam Report, 2018). The excerpts of Moneycontrol (2019) state that Indian Chief Executive Officer's (CEO) Pay has outpaced company performance in the last five years. As per ET Bureau (2019) reports, the average pay of MDs and CEOs for FY19 was 6.39 crore as compared to 5.53 crore and 4.49 crore in FY 18 and FY 17, respectively. In September 2019, the case of Altico Capital (India-based NBFC) sent shockwaves to the country as it decided to pay its CEO more than half the money it had defaulted to Mashreq Bank in Dubai (U.A.E), as reported by ET Prime (2019).

To bring about enhanced transparency, better governance and ethical way of conducting business, India has legislated several reforms in Companies Act 2013 and SEBI guidelines. With a provision to spend about 2\% of the average net profits of preceding three financial years towards the cause of corporate social responsibility (CSR) (under Section 135, Companies Act, 2013), India became the first country in the world to make such a legal enactment. With an acknowledgement to disclose the remuneration of the executives, the Ministry of Corporate Affairs in the Amended Managerial Remuneration Rules, 2016 obligated all the listed companies to mention the name of top 10 employees (in terms of remuneration drawn), in its Board Report or to the Registrar of Companies (ROC) as and when required. This study focuses on India as an emerging economy where regulations are getting stringent to work for and protect the interest of the investors/stakeholders.

The CEO is considered to be the most powerful figure in a firm (Li et al., 2016) and is expected to take a relatively lower pay to reduce firm risk and maintain harmony with the stakeholders in socially responsible firms (also referred to as ESG firms), thereby posing themselves as "an exemplary CEO". CEO acts as a nexus between the stakeholders and encourages greater CSR engagement rather than being too much concerned about its own benefit (Cai et al., 2011). ESG firms carrying out CSR activities is proved to reduce cash-flow risk and is also being used as an intangible asset for a long-term purpose to benefit the interest of all the stakeholders (Chan et al., 2014; Gao \& Zhang, 2013; Miles \& Miles, 2013; Mukhtaruddin et al., 2019; Ronald et al., 2019). While CSR represents efforts made by the company to create a positive impact to the internal as well as external stakeholders; ESG disclosure is a systematic assessment of such activities carried out by the organization. ESG Disclosure Scores reported by various agencies is a reflection of ESG transparency and is also considered by the investors as a proxy for "management quality" assessment (Eccles et al., 2011). Previous studies carried out in this domain largely focused on CSR disclosure or CSR performance; while ESG transparency measure (when taken as a substitute for (SR) would bring out a standardized quantifiable metrics that would aid in better reliability, comparability, and consistency within/across industry groups.

There has been abundant research literature depicting the inter-relationship between CSR, CEO compensation and firm performance. Broadly, these studies stem from two Schools of Thought-the

1. The words pay, remuneration and compensation has been used synonymously in this paper. 
"over-investment hypothesis" based on agency theory and the "conflict-resolution hypothesis" based on the stakeholder theory (Cai et al., 2011). The "over-investment hypothesis" argues that managers try to over-invest in CSR activities to enhance their reputation which would eventually destroy the firm value (Barnea \& Rubin, 2010). But, it would benefit the CEO with more bargaining power, growth opportunities, career progression, etc. (Milbourn, 2003) that would eventually help them in settling for a higher pay. On a reverse note, the "conflict-resolution hypothesis" stresses the fact that firms use CSR engagement as a tool to reduce conflicts between the managers and non-investing stakeholders. This would lead to an increase in firm value and eventually resulting to a lesser compensation payment to CEOs (Freeman, 1984; Jo \& Harjoto, 2011; Karim et al., 2018).

All said and done in general, there still remains numerous firm, board and CEO-related attributes that also impact pay to a great extent. Earlier studies like Burke and Day (1986), Core et al. (1999), Murphy (1999), Ghosh (2003), Jaiswall and Firth (2009) have incorporated firm size into their regression models as an explanatory variable. There are evidences that smaller firms may not exhibit as many overt socially responsible behaviors as the larger firms do as the bigger size firms is always under the scrutiny of the public and special-interest groups (Roberts, 1992). In contrast, Baumann-Pauly et al. (2013) argue that larger firms have internal implementation constraints when it comes to CSR practices. With respect to leverage of the firm, studies like Ross (1977), Jensen (1986), Lewellen et al. (1987), John and John (1993), Mehran (1995) have brought out the relation of debt financing and its corresponding effect on pay-performance concept. Leverage is considered as an alternative to the remuneration pay for firms having high cash-flows that can exert managerial discipline and enhance critical observation of use of debt-finance by the managers. Mishra and Modi (2013) have argued that financial leverage is an important moderating variable as higher leverage would lower the risk-reduction benefit that would arise from positive CSR. Family ownership and group control is another firm attribute that dominates the corporate sector in India, wherein separate legal entities are connected together by a single promoter (Narayanaswamy et al., 2012) and therefore classification on the basis of group or standalone firm is an important aspect of the study.

Apart from the attributes stated above, there are other CEO and board- specific factors that have been considered as controls affecting the CEO pay for the chosen sample. This is because corporate governance measures are considered as key instruments that drive good performance (Suteja et al., 2017). Gender diversity in board results in preventing larger pay gaps (Rekker et al., 2014) and helps in reducing environmental violations as they are more concerned about the welfare of third-party stakeholders (Liu, 2018). Therefore, female CEO and women in board are hypothesized to have a negative relationship with compensation. Jizi et al. (2014) in their studies have exclaimed that CEO-Chairman duality is a sign of managerial power and have found a positive relationship with CSR disclosure that promote good citizenship. Cai et al. (2011) have taken CEO duality as an instrumental variable proxy for CEO power and have found a significant negative relation between CEO compensation and CSR. As Brockman et al. (2016) implicit that outsider CEOs possess generalist skills, while insiders imbibe specialist skills; Murphy and Zabojnik (2004) state that compensation is positively correlated with general skills and knowledge possessed by the CEOs. With respect to firms having co-CEOs in their board, Arena et al. (2011) have claimed that co-CEO teams are more expensive than single CEO as the former exhibit shared power, skill-sets and responsibility in an organization that ultimately helps in increasing firm valuation. Board size and board independence are two widely used variables in compensation literature (Cai et al., 2011; Ghosh, 2006a, 2006b; Jaiswall \& Bhattacharyya, 2016; Rekker et al., 2014; Tomar \& Korla, 2011), but the results show a mixed relationship with CEO pay. While some studies show that increasing board size would reduce good governance leading to higher compensation, a group of other works states that smaller as well as independent boards can constrain the CEO through better monitoring and letting them settle for a lower pay. Although board 
size and independence significantly influences the ESG scores and sustainability compensation policies, presence of a CSR committee within the organization triggers better non-financial performance (Baraibar-Diez et al., 2019).

The purpose of this paper can be summarized in three ways. First, to identify whether ESG transparency strengthens the impact of performance on CEO pay in socially responsible firms (ESG disclosure scores from Bloomberg is taken as a proxy for transparency). Second, to segregate the controlling groups into three attributes (i.e. firm controls, CEO controls, board controls) and determine the impact of ESG transparency in each of their sub-components. Finally, to categorize disclosure score into ESG, environmental, social and governance factors that would enrich the results by depicting influence of each one of them on the pay-performance relationship of sustainable firms.

\section{METHODS}

\section{Data of ESG Companies}

Keeping our prime objective in mind, we have considered companies in NSE NIFTY ${ }^{2} 100$ ESG Index as our sample, as it reflects the companies' performance based on the Environmental, Social and Governance (ESG) factors. Data were collected in the year 2019 and all the companies are listed in the index for the year ended 31st March 2019 have been considered for the study. To be placed in the stated sample list, every company needs to be primarily categorized under NIFTY 100 Index first and should have a valid ESG score. Starting with a base value of 1,000 as on 1st April 2011; these stocks derive their weights from its free-float market capitalization on a bi-annual basis. Firms which have an ESG score of 4 and 5 (as the rating scale shall range from 1 to 5 wherein 1 , 2 or 3 indicates a valid score while 4 or 5 indicates an invalid score) or are engaged in anti-environmental businesses like manufacturing of weapons, gambling, alcohol and tobacco will not qualify to be listed in the above index.

Initially, a total of 90 companies were extracted from NSE NIFTY 100 ESG Index and data were collected from Centre for Monitoring Indian Economy (CMIE) Prowess Database which was then further filtered as per the availability of all the other necessary variables. The Prowess database is one of the leading databases in India which derives a large chunk of information from the annual reports of over 40,000 companies from different industrial sectors. Following Chakravarthy (1986), Khanna and Palepu (2000), Ghosh (2006a, 2006b) this database was considered for the study. Out of the above sample, financial service firms like banking and insurance sectors have been excluded as they are governed by their respective special acts and not Companies Act 2013. The final sample consists of a balanced panel of 67 firms for 6 years spanning from 2014 to 2019 resulting in 402 firm-year observations. The list of selected companies as on 31st March 2019 is given in Appendix 1.

The total compensation paid to the CEO or managing director (as designated by the corporate law in India) is taken as the dependent variable in the current study. Total remuneration includes the fixed as well as variable pay components, viz., base salary, commission, or bonus for performance, contribution toward provident fund, retirement benefits, and stock options. In order to standardize the remuneration figures for different firms, log of pay is considered as the explained variable.

\footnotetext{
2. NSE stands for National Stock Exchange of India and Nifty 100 is a benchmark index of the Indian stock market representing the largest Indian companies listed in NSE.
} 
As a proxy for ESG Transparency, Bloomberg ESG Disclosures scores have been taken as an independent variable that measures the amount of environmental, social, and governance data disclosed to the public in its company reports (Tamimi \& Sebastianelli, 2017; Yu et al., 2018). Bloomberg database collects and compiles ESG data for over 10,000 listed companies globally; which helps the investors in assessing the overall transparency through these scores assigned to them. The scores range from 0.1 to 100 (ranging from lowest to highest) based on different parameters in each of the three categories (Patnaik \& Suar, 2020). Thus, these quantitative scores have been used in the current study as a measure of transparency disclosure, rather than focusing on the actual ESG performance.

Table 1. Variable Definition

\begin{tabular}{|c|c|}
\hline Variables & Description \\
\hline \multicolumn{2}{|c|}{ Dependent Variable } \\
\hline COMP & $\begin{array}{l}\text { Natural logarithm of compensation paid to the CEO or managing director in a financial } \\
\text { year (pay includes total of basic salary, bonus/commission, provident fund contribution, } \\
\text { retirement benefits, perquisites and stock options granted) }\end{array}$ \\
\hline \multicolumn{2}{|c|}{ ESG Transparency Variables } \\
\hline ESG & $\begin{array}{c}\text { A combined disclosure score of overall ESG transparency of an individual firm as rated } \\
\text { by the Bloomberg database. }\end{array}$ \\
\hline Env & $\begin{array}{c}\text { An indicator/disclosure score of environmental transparency of an individual firm as } \\
\text { given in the Bloomberg database. }\end{array}$ \\
\hline Social & $\begin{array}{c}\text { An indicator/disclosure score of social transparency of an individual firm as specified in } \\
\text { the Bloomberg database }\end{array}$ \\
\hline Gov & $\begin{array}{c}\text { An indicator/disclosure score of transparency in governance of an individual firm as } \\
\text { rated by the Bloomberg database }\end{array}$ \\
\hline \multicolumn{2}{|c|}{ Firm Performance Variables } \\
\hline ROA & Ratio of PBDITA less depreciation/amortization to the total assets \\
\hline ROE & ROE or net worth \\
\hline T-Q & $\begin{array}{l}\text { Ratio of total assets plus market capitalization minus book value of equity to total } \\
\text { assets }\end{array}$ \\
\hline Return & Annual NSE stock returns that includes dividend and capital growth/appreciation \\
\hline \multicolumn{2}{|c|}{ Firm-Specific Controls } \\
\hline F_Size & Natural logarithm of total assets of the firm \\
\hline LEV & Ratio of total of short-term and long-term borrowings to total assets \\
\hline Ownership & $\begin{array}{l}\text { A dichotomous variable that takes value as } 1 \text { if the individual firm belongs to a "group" } \\
\text { and value as } 0 \text { if it is a "standalone" firm }\end{array}$ \\
\hline \multicolumn{2}{|c|}{ CEO-Specific Controls } \\
\hline F_CEO & $\begin{array}{c}\text { A dichotomous variable that takes value as } 1 \text { if the firm has a female CEO and value } 0 \\
\text { otherwise }\end{array}$ \\
\hline Insider CEO & $\begin{array}{c}\text { A dummy variable that takes } 1 \text { if CEO/MD is appointed from within the organization in } \\
\text { succession or o otherwise }\end{array}$ \\
\hline CEO Duality & $\begin{array}{c}\text { A dummy variable that takes } 1 \text { if CEO/MD is also the chairperson/chairman of the board } \\
\text { of directors or } 0 \text { otherwise }\end{array}$ \\
\hline CO-CEO & $\begin{array}{l}\text { A dichotomous variable that takes value as } 1 \text { if the firm has two or more CEO's in a year } \\
\text { (OR) has appointed co-CEOs concurrently in a year and value o otherwise }\end{array}$ \\
\hline \multicolumn{2}{|c|}{ Board-Specific Controls } \\
\hline Board Size & The total number of board of directors present at the end of the financial year \\
\hline Board Ind & $\begin{array}{c}\text { The percentage of independent directors out of the total directors present at the end of } \\
\text { the financial year }\end{array}$ \\
\hline CSR COM & $\begin{array}{l}\text { A dichotomous variable that takes its value as } 1 \text { if the company has constituted a } \\
\text { Sustainability/CSR committee or value o otherwise }\end{array}$ \\
\hline Women Board & The percentage of women directors in the board as a proxy for board gender diversity \\
\hline
\end{tabular}


Both accounting and market measures of firm performance have been considered as explanatory variables. Following Cowen et al. (1987), Waddock and Graves (1997), McWilliams and Siegel (2001), Raithatha and Komera (2016), and Mishra and Kapil (2017); return on assets (ROA) and return on equity (ROE) are taken as proxies for accounting-based measure and Tobin's $Q$ and annual stock return are taken as representatives for market-based measures.

The control variables affecting the compensation are classified under three heads: firm-specific, CEO-specific and board-specific controls.

Firm size (as used by Jaiswall \& Bhattacharyya, 2016; Raithatha \& Komera, 2016; Spicer, 1978), financial leverage (following Ghosh, 2006a, 2006b; Raithatha \& Komera, 2016), and ownership for group or standalone firms (also considered by Jaiswall \& Bhattacharyya, 2016) are taken as control variables as they can enormously affect the pay-performance relationship. Data for all the above-mentioned variables have been extracted from CMIE Prowess database and individual annual reports in case of data insufficiency; the description of which has been given in Table 1.

Controlling for CEO-specific attributes include female CEO as a gender-diversity measure (Jadiyappa et al., 2019; Khan \& Vieito, 2013), insider CEO as a successor (also used by Brockman et al., 2016), CEO duality (following Brickley et al., 1997; Li et al., 2016) and co-CEO factors (also studied by Arena et al., 2011). Data relating to these measures are taken as dummy variables and has been collected from Bloomberg database.

Apart from the firm and CEO controls, several other board attributes have also been included as controlling factors of CEO pay. These include: size of the board (following Core et al., 1999; Rekker et al., 2014; Tomar \& Korla, 2011), percentage of independent directors out of total board directors (Cai et al., 2011; Jaiswall \& Bhattacharyya, 2016; Jian \& Lee, 2015), number of women directors present in the board (also included by Anazonwu et al., 2018) and the constitution of CSR/Sustainability Committee (also considered by Baraibar-Diez et al., 2019). As like CEO attributes, board-related factors are also extracted from Bloomberg database.

\section{Model/Methodology}

The methodology used for the study is two-step system GMM (a dynamic panel data estimator) as it has the potential to handle endogeneity, heteroskedasticity and autocorrelation issues in a single framework. System-GMM estimator stated by Blundell and Bond (1998) is an improvement over the difference GMM, as it can accommodate more instruments in order to enhance efficiency. To address the issue of omitted variable bias, endogeneity and reverse causality in a set of "small T and large N" panels; generally system GMM builds two equations (original equation and first difference equation) to solve the above issue by taking differenced variable as instruments in the level equation. Further classification subdivides the system GMM into two categories-(a) one-step system GMM and (b) two-step system GMM. Roodman (2009) mentioned that two-step GMM is an advanced model over the one-step as it is highly robust to heteroskedasticity and autocorrelation issues, thus giving a better clarity and reliability in the results.

The basic autoregressive dynamic model has the following notation:

$$
\log (\operatorname{COMP})_{i t}=\alpha_{0+}+\varnothing \log (\operatorname{COMP})_{i t-1}+\beta_{1} Y_{i t}+\gamma Z_{i t}+d_{t}+\varepsilon_{i t}
$$

Wherein, COMP is the dependent variable for consolidated CEO compensation for ith company and time $t, Y_{i t}$ is the performance measure for ith company at " $t$ " time, $z_{i t}$ is the vector of other related ESG transparency measures or control variables that affect the dependent variable for ith company at time " $t$ ", $d_{t}$ is the time dummies taken as 0 or 1 for all the years and $\varepsilon_{\text {it }}$ is the error term/residuals for ith company at time $t$. 


\section{RESULTS AND DISCUSSION}

\section{Univariate Tests}

To start with the analysis, unit-root stationarity of all the variables is tested through two different methods (Levin, Lin \& Chu and Im, Pesaran \& Shin W-stat) and all the measures were found to be stationary at level. Initially, a summary of univariate test results were obtained through descriptive statistics and Pearson's correlation matrix as shown in Tables 2 and 3, respectively.

Table 2 summarizes the total number of observations, average, standard deviation, minimum and maximum values for compensation, ESG measures, performance variables and other control variables. The average compensation of the CEO or MD is reported to be 12.4 crores with a deviation of 18.3 crores. Owing to the presence of high positive skewness in the sample (some CEOs are paid enormously higher as compared to others), logarithm of compensation measure has been taken as a dependent variable in the final model. While the average ESG disclosure scores stand at 34.89, corporate governance disclosure scores shows a quite high mean of 52.27 followed by social and environmental scores of 41.02 and 25.57 , respectively (consistent with Tamimi \& Sebastianelli, 2017).

To explore the impact of performance on pay, both accounting and market-based measures of performance has been reported. While mean figure of ROA and ROE is $16.1 \%$ and $20.79 \%$, respectively, average of

Table 2. Descriptive Statistics

\begin{tabular}{lccccc}
\hline Variable & Obs & Mean & Std. Dev. & Min & Max \\
\hline $\begin{array}{l}\text { Dependent Variable } \\
\text { COMP (total in thousands) }\end{array}$ & 402 & 124,000 & 183,000 & 262,801 & $1,660,000$ \\
ESG Transparency Variables & & & & & \\
ESG & 402 & 34.896 & 13.767 & 9.09 & 61.16 \\
Env & 402 & 25.573 & 17.551 & 2.326 & 63.57 \\
Social & 402 & 41.023 & 14.12 & 7.02 & 71.93 \\
Gov & 402 & 52.277 & 7.716 & 19.767 & 69.643 \\
Firm Performance Variables & & & & \\
T-Q & 402 & 5.385 & 5.983 & 0.74 & 37.117 \\
ROA & 402 & 0.161 & 0.113 & -0.174 & 0.792 \\
ROE & 402 & 20.793 & 23.695 & -33.51 & 315.09 \\
Return & 402 & 0.062 & 1.897 & -9.95 & 6.72 \\
Firm-Specific Controls & & & & & \\
F_Size & 402 & 5.351 & 0.509 & 4.168 & 6.89 \\
LEV & 402 & 0.114 & 0.133 & 0 & 0.543 \\
Ownership & 402 & 0.716 & 0.451 & 0 & 1 \\
CEO-Specific Controls & & & & \\
F_CEO & 402 & 0.027 & 0.163 & 0 & 1 \\
Insider CEO & 402 & 0.612 & 0.488 & 0 & 1 \\
CEO Duality & 402 & 0.261 & 0.44 & 0 & 1 \\
Co-CEO & 402 & 0.082 & 0.275 & 0 & 1 \\
Board-Specific Controls & & & & \\
Board Size & 385 & 11.244 & 2.532 & 6 & 22 \\
Board Ind & 385 & 51.06 & 12.5 & 0 & 1 \\
CSR COM & 0.881 & 0.325 & 0 & 42.857 \\
Women Board & 402 & 7.935 & 0 & \\
\hline
\end{tabular}


Table 3. Correlation Matrix

\begin{tabular}{|c|c|c|c|c|c|c|c|c|c|c|c|c|c|c|c|c|c|c|c|c|}
\hline & (1) & (2) & (3) & (4) & (5) & (6) & (7) & (8) & (9) & (10) & (11) & (12) & (13) & (14) & (15) & (16) & (17) & (18) & (19) & (20) \\
\hline (1) COMP & 1 & 1 & & & & & & & & & & & & & & & & & & \\
\hline (2) ESG & $0.18^{*}$ & 1 & & & & & & & & & & & & & & & & & & \\
\hline (3) Env & $0.18^{*}$ & $0.94^{*}$ & 1 & & & & & & & & & & & & & & & & & \\
\hline (4) Social & 0.05 & $0.79^{*}$ & $0.69^{*}$ & 1 & & & & & & & & & & & & & & & & \\
\hline (5) Gov & $0.22^{*}$ & $0.75^{*}$ & $0.67^{*}$ & $0.53^{*}$ & 1 & & & & & & & & & & & & & & & \\
\hline (7) ROA & 0.05 & $-0.15^{*}$ & $-0.15^{*}$ & $-0.13^{*}$ & -0.09 & $0.49^{*}$ & 1 & & & & & & & & & & & & & \\
\hline (8) ROE & 0.04 & $-0.13^{*}$ & $-0.14^{*}$ & -0.09 & -0.07 & $0.43^{*}$ & $0.64^{*}$ & 1 & & & & & & & & & & & & \\
\hline (9) Return & 0.04 & 0.02 & 0.03 & -0.01 & 0.08 & -0.00 & 0.00 & -0.03 & 1 & & & & & & & & & & & \\
\hline (10) F-Size & 0.01 & $0.43^{*}$ & $0.34^{*}$ & $0.43^{*}$ & $0.39^{*}$ & $-0.51^{*}$ & $-0.37^{*}$ & $-0.27^{*}$ & -0.01 & 1 & & & & & & & & & & \\
\hline (11) LEV & -0.07 & 0.05 & 0.01 & $0.15^{*}$ & 0.09 & $-0.38^{*}$ & $-0.53^{*}$ & $-0.26^{*}$ & -0.04 & $0.57^{*}$ & 1 & & & & & & & & & \\
\hline (13) F_CEO & -0.05 & -0.07 & -0.09 & -0.03 & -0.08 & -0.051 & 0.04 & 0.04 & 0.01 & -0.02 & -0.03 & -0.06 & 1 & & & & & & & \\
\hline (14) Insider CEO & 0.04 & 0.02 & 0.07 & -0.08 & 0.08 & $0.20^{*}$ & 0.09 & 0.02 & -0.07 & -0.04 & $-0.12^{*}$ & $0.12^{*}$ & 0.01 & 1 & & & & & & \\
\hline (15) CSR COM & 0.05 & $0.11^{*}$ & 0.07 & $0.13^{*}$ & $0.10^{*}$ & -0.05 & -0.01 & $-0.13^{*}$ & 0.01 & $0.18^{*}$ & 0.09 & 0.02 & 0.01 & 0.01 & 1 & & & & & \\
\hline (16) Co-CEO & -0.02 & 0.09 & $0.09^{*}$ & 0.05 & 0.02 & -0.07 & -0.02 & -0.01 & 0 & 0.05 & 0.01 & $-0.13^{*}$ & 0.01 & -0.08 & -0.01 & 1 & & & & \\
\hline (17) Board Size & 0.03 & 0.08 & 0.08 & $0.12^{*}$ & 0.06 & 0.01 & $-0.11^{*}$ & $-0.15^{*}$ & 0.01 & $0.19^{*}$ & $0.11^{*}$ & -0.04 & -0.05 & -0.02 & -0.04 & 0.06 & 1 & & & \\
\hline (18) Board Ind & $0.21^{*}$ & $0.17^{*}$ & $0.21^{*}$ & 0.05 & $0.22^{*}$ & 0.09 & -0.01 & -0.03 & 0.06 & -0.07 & -0.09 & $0.48^{*}$ & -0.07 & $0.19^{*}$ & 0.07 & -0.02 & 0.09 & 1 & & \\
\hline (19) CEO Duality & $-0.18^{*}$ & 0.06 & 0.01 & $0.24^{*}$ & 0.01 & $-0.21^{*}$ & -0.07 & -0.03 & -0.06 & $0.21^{*}$ & $0.24^{*}$ & $-0.51^{*}$ & 0.04 & 0.04 & 0.08 & -0.01 & 0.01 & $-0.24^{*}$ & 1 & \\
\hline (20) Women Board & 0.01 & -0.07 & -0.09 & -0.02 & -0.04 & -0.03 & 0.02 & -0.01 & -0.07 & 0.01 & 0.01 & $0.14^{*}$ & $0.10^{*}$ & -0.02 & $0.13^{*}$ & -0.03 & $-0.17^{*}$ & 0.07 & $-0.13^{*}$ & 1 \\
\hline
\end{tabular}

Note:* significant at $1 \%$ level 
stock returns and Tobin's Q ratio stands at 6.2\% and 5.38\%, respectively. Other control measures show that on an average there are around 11 directors in a company board out of which $51 \%$ are independent and $12 \%$ are female directors. Further, $72 \%$ of the firms are either family-owned or group companies and only $3 \%$ have a female CEO as company head.

Table 3 gives the association between variables through Pearson's correlation table. ESG, environmental and governance disclosure score shows a significant positive association with compensation, while the social disclosure score does not. While ownership holdings and board independence show a positive significant relationship with pay, CEO duality shows a significant negative association with the same. Although, other variables do not establish significant correlation with the pay measure, but they definitely do reveal a positive or negative association.

\section{Multivariate Test and Key Findings}

After having determined the univariate statistics, the paper proceeds for the multivariate tests using the system GMM methodology. Table 4 gives the results of dynamic panel data estimation using two-step system GMM (xtabond2 command in Stata). The results are presented in the table which consists of five different model specifications. While model 1 shows the impact of performance on pay without disclosure scores, model 2 depicts the role of ESG transparency in the pay-performance relationship. The last three models segregate various components of disclosure scores in order to determine the impact of each one by controlling for multicollinearity issue which might arise when factors are taken together. Time dummies have also been considered for the entire period of the sample to control for the time-specific fixed effects which arenot dealt with by other independent variables.

As logarithm of CEO compensation is taken as a dependent variable, one year lag of pay shows high positive significance to the current value in all the cases/models. This implies that the contemporaneous value of pay depends on its lagged figures in case of sample ESG firms (findings similar to Raithatha \& Komera, 2016). The results of the first model reveal an insignificant negative relationship of Tobin's $Q(-0.005)$ and ROA (-0.462) with the CEO pay while stock returns $(-0.013)$ show a significant negative figure. When an overall ESG disclosure score is included in model 2, the results show a considerable and significant improvement. While the ROE figure is significant in both the cases, the magnitude of its impact is quite negligible (i.e. the coefficients are small). But the other measures of firm performance-Tobin's $Q(-0.007)$, ROA (-0.727) and stock returns to investors $(-0.011)$ show a highly significant negative relationship with the compensation paid to the CEOs. This shows that a large portion of the total CEO pay in socially responsible firms is associated with transparency in ESG disclosures. The results support conflict-resolution hypothesis that implies CEOs in socially responsible firms settle for a lower pay with an increase in firm performance (similar to findings of Cai et al., 2011). Accounting measures of ROA show quite a high negative significance-meaning compensation is largely affected by accounting measures of performance, rather than stock market value (Jensen \& Murphy, 1990). With more ESG reporting as well as increase in returns on firm assets, the pay reduces.

The results of control variables remain the same for both the models except for firm size and CEO duality in the second model. While firm size shows a significant negative association with compensation, CEO-Chairman duality has a significant positive association. It can be opined that with the increase in firm size, the reporting increases and remuneration pay decreases. On the other hand, a dual CEO is considered to be more powerful and therefore takes a higher pay. Firm leverage, CSR committee constitution and percentage of women directors in the board remains insignificant and shows no relationship with the pay drawn by the CEOs. 
Table 4. Results for Two-Step System GMM as a Dynamic Panel Data Estimator

\begin{tabular}{|c|c|c|c|c|c|}
\hline \multirow[b]{2}{*}{ COMP } & \multicolumn{5}{|c|}{ Dynamic Panel Data Estimation-Two-Step System GMM } \\
\hline & Model 1 & Model 2 & Model 3 & Model 4 & Model 5 \\
\hline Constant & $0.883^{*}(0.457)$ & $1.359^{* * *}(0.35)$ & $1.403^{* * *}(0.422)$ & $0.768 * * *(0.255)$ & $1.166 * * *(0.233)$ \\
\hline F_Size & $-0.044(0.043)$ & $-0.122 * * *(0.030)$ & $-0.117 * * *(0.032)$ & $-0.051 *(0.03)$ & $-0.095 * * *(0.025)$ \\
\hline LEV & $-0.056(0.117)$ & $-0.073(0.095)$ & $-0.071(0.095)$ & $0.003(0.089)$ & $-0.054(0.073)$ \\
\hline Ownership & $0.308 * * *(0.062)$ & $0.288 * * *(0.04)$ & $0.299 * * *(0.044)$ & $0.267 * * *(0.026)$ & $0.237^{* * *}(0.029)$ \\
\hline F_CEO & $-0.159 * *(0.075)$ & $-0.093^{* * *}(0.021)$ & $-0.055^{*}(0.031)$ & $-0.132 * * *(0.042)$ & $-0.059 *(0.031)$ \\
\hline Insider CEO & $0.082 * * *(0.023)$ & $0.043^{* * *}(0.015)$ & $0.047^{* * *}(0.015)$ & $0.055^{* * *}(0.013)$ & $0.034 * *(0.013)$ \\
\hline CSR COM & $0.135(0.084)$ & $0.094(0.058)$ & $0.06(0.07)$ & $0.125 * *(0.048)$ & $0.037(0.046)$ \\
\hline Co-CEO & $0.203^{* * *}(0.060)$ & $0.136 * * *(0.038)$ & $0.163^{* * *}(0.045)$ & $0.161 * * *(0.043)$ & $0.153^{* * *}(0.041)$ \\
\hline Board Size & $0.019 * *(0.007)$ & $0.021 * * *(0.004)$ & $0.019 * * *(0.01)$ & $0.023 * * *(0.003)$ & $0.017^{* * *}(0.002)$ \\
\hline Board Ind & $-0.014 * * *(0.004)$ & $-0.009 * * *(0.001)$ & $-0.012 * * *(0.006)$ & $-0.009 * * *(0.001)$ & $-0.007 * * *(0.001)$ \\
\hline CEO Duality & $0.045(0.037)$ & $0.044 * *(0.02)$ & $0.051 *(0.028)$ & $0.045^{* *}(0.02)$ & $0.017(0.024)$ \\
\hline Women Board & $0.001(0.001)$ & $0.001(0.00)$ & $0.001(0.001)$ & $0.001(0.000)$ & $0.001(0.000)$ \\
\hline $\mathrm{COMP}_{\mathrm{it}-1}$ & $0.937 * * *(0.004)$ & $0.887^{* * *}(0.029)$ & $0.912 * * *(0.037)$ & $0.923^{* * *}(0.019)$ & $0.871 * * *(0.021)$ \\
\hline $\mathrm{T}-\mathrm{Q}$ & $-0.005(0.004)$ & $-0.007 * * *(0.002)$ & $-0.005(0.003)$ & $-0.008 * * *(0.002)$ & $-0.005^{* *}(0.002)$ \\
\hline ROA & $-0.462(0.291)$ & $-0.727^{* * *}(0.194)$ & $-0.650 * * *(0.226)$ & $-0.540 * * *(0.191)$ & $-0.445^{* *}(0.177)$ \\
\hline ROE & $0.003 * *(0.001)$ & $0.004^{* * *}(0.001)$ & $0.002 * *(0.001)$ & $0.004 * * *(0.000)$ & $0.002 * *(0.001)$ \\
\hline Return & $-0.013 * *(0.005)$ & $-0.011 * * *(0.003)$ & $-0.013^{* * *}(0.003)$ & $-0.007 *(0.003)$ & $-0.017 * * *(0.003)$ \\
\hline ESG & & $0.004 * * *(0.001)$ & & & \\
\hline Env & & & $0.003^{* * *}(0.001)$ & & \\
\hline Social & & & & $-0.001(0.001)$ & \\
\hline Gov & & & & & $0.006 * * *(0.002)$ \\
\hline Time-effect & Yes & Yes & Yes & Yes & Yes \\
\hline Hansen Test ( $p$-value) & 0.545 & 0.412 & 0.435 & 0.58 & 0.291 \\
\hline F-Statistics ( $p$-value) & $242.85(0.000)$ & $6,423.85(0.000)$ & $13,125.80(0.000)$ & $176,482.11(0.000)$ & $7,328.66(0.000)$ \\
\hline $\operatorname{AR}(1)$ & 0.001 & 0.000 & 0.001 & 0.001 & 0.000 \\
\hline $\operatorname{AR}(2)$ & 0.790 & 0.635 & 0.619 & 0.825 & 0.637 \\
\hline No. of instruments & 56 & 67 & 67 & 67 & 67 \\
\hline No. of groups & 67 & 67 & 67 & 67 & 67 \\
\hline No. of firm-year observations & 322 & 322 & 322 & 322 & 322 \\
\hline
\end{tabular}

Note: * significance at $10 \%, * *$ significance at $5 \%, * * *$ significance at $1 \%$ 
Group ownership, insider CEO, presence of CO-CEOs and size of the board is significantly positive to the CEO compensation. Finally, the presence of an independent board and an appointment of a female CEO in the company show a negative relationship with pay figures.

In order to get a clear picture of the impact of specific components of ESG, three measures, viz., environmental, social and governance has been tested separately in model 3, model 4 and model 5 , respectively. While ESG disclosure scores in model 2 is positively significant, environmental disclosure scores (model 3) and governance disclosure scores (model 5) also give similar results. With higher disclosure scores and more transparency in ESG firms, compensation increases by a smaller margin. The findings support the fact that corporate governance disclosures have a high impact as compared to other measures for the obvious reason that there are stringent governance regulations in India while environmental/social laws are not quite evolved. Social transparency has an insignificant negative association with pay, but CSR Committee shows significance when the former measure is included.

Table 4 indicates the two-step system GMM results. Below the coefficients are the standard errors reported in parentheses.

\section{Model-Fit and Diagnostics Tests}

Dynamic panel estimation using generalized methods of moments is capable of correcting for heterogeneity arising out of unobserved firm as well as time-invariant effects, measurement error, omitted variable bias, persistence and endogeneity problem arising out of an estimation procedure (Caselli et al., 1996; Lilling, 2006). Specifically, system GMM is suitable for corporate governance studies with data sets having moderate time periods wherein some variables are endogenous and there exists a dynamic relationship between variables (Sheikh et al., 2018). With 67 firms ranging over six years (i.e. $N>T$ ), the current data sample is suitable for applying system GMM. CEO compensation is treated as a dynamic variable as it shows persistence and is affected by past realizations. Explanatory variables like disclosure scores and firm performance are considered as endogenous and the rest is considered as exogenous variables. This model requires specification of lag length criteria, hence lag ( 23 ) has been used in all cases.

The overall validity of the model can be determined using F-test ( $p$-value) which is significant in all the cases in our analysis. The Hansen test specifies the overall validity of the instruments with a null hypothesis stating "instruments as group are exogenous". As the $p$-value of Hansen test is able to successfully accept the null hypothesis in all the cases $(p>0.10)$, conclusion can be drawn that instruments used are robust and exogenous. Another important consideration for this model is that number of instruments should be less than or equal to the number of groups to avoid over-identification; which is adhered to in all the specifications. Other diagnostic tests include the check for autocorrelation or serial correlation using AR1 and AR2 statistics. While $A R 1$ shows the first-order serial autocorrelation (i.e. differenced error term is serially correlated at $A R 1$ ), $A R 2$ is considered as an important test that detects autocorrelation at levels. The null hypothesis of AR2 statistics indicates "there exists no autocorrelation in the error term" which gets accepted in all the cases giving an indication of no serial autocorrelation in the model.

\section{CONCLUSION}

The CEO being at the helm of affairs of a company plays a crucial role in determining organization's progress towards strategic decision-making (Malik et al., 2020). It also plays a key role in CSR which is positively related to 
subsequent firm performance (Bachmann et al., 2020). Thus, ultimately there exists a strong relationship between CEO compensation and firm performance (Hall \& Liebman, 1998). In this paper, an attempt has been made to study the role of ESG transparency in determining the impact of firm performance on CEO compensation in socially responsible companies. The results are in support of conflict-resolution hypothesis showing that when there is a transparent ESG disclosure mechanism and an increase in ROA, Tobin's Q or stock returns, there is a reduction in compensation paid to the CEOs. As like in US socially responsible firms, Indian CEOs are sacrificing their greed (Cai et al., 2011) and engaging themselves in environmental, community, and employee welfare activities.

The current study focuses on ESG transparency in quantitative terms which is not capable of measuring quality or specific-traits of disclosure policies. Future researchers can work on ESG quality and with different indexes from various databases. The performance-linked variable pay of the CEOs can be considered instead of total compensation and can be applied in different time frames of other countries. With the COVID-19 pandemic engulfing the world in its claws, corporate houses and CEOs can make a difference by working and contributing largely for the benefit of the community.

\section{ORCID}

Chetna Rath (1) http://orcid.org/0000-0002-7312-6136

Florentina Kurniasari (D) http://orcid.org/0000-0003-2288-7389

\section{REFERENCES}

Anazonwu, H. O., Egbunike, F. C., \& Gunardi, A. (2018). Corporate board diversity and sustainability reporting: A study of selected listed manufacturing firms in Nigeria. Indonesian Journal of Sustainability Accounting and Management, 2(1), 65-78. https://doi.org/10.28992/ijsam.v2i1.52.

Arena, M. P., Ferris, S. P., \& Unlu, E. (2011). It takes two: The incidence and effectiveness of co-CEOs. Financial Review, 46(3), 385-412. https://doi.org/10.1111/j.1540-6288.2011.00305.x.

Bachmann, R. L., Loyeung, A., Matolcsy, Z. P., \& Spiropoulos, H. (2020). Powerful CEOs, cash bonus contracts and firm performance. Journal of Business Finance \& Accounting, 47(1-2), 100-131. https://doi.org/10.1111/ jbfa.12410.

Baraibar-Diez, E., Odriozola, M. D., \& Fernández Sánchez, J. L. (2019). Sustainable compensation policies and its effect on environmental, social, and governance scores. Corporate Social Responsibility and Environmental Management, 26(6), 1457-1472. https://doi.org/10.1002/csr.1760.

Barnea, A., \& Rubin, A. (2010). Corporate social responsibility as a conflict between shareholders. Journal of Business Ethics, 97(1), 71-86. https://doi.org/10.1007/s10551-010-0496-z.

Baumann-Pauly, D., Wickert, C., Spence, L. J., \& Scherer, A. G. (2013). Organizing corporate social responsibility in small and large firms: Size matters. Journal of Business Ethics, 115(4), 693-705. https://doi.org/10.1007/ s10551-013-1827-7.

Blundell, R., \& Bond, S. (1998). Initial conditions and moment restrictions in dynamic panel data models. Journal of Econometrics, 87(1), 115-143. https://doi.org/10.1016/S0304-4076(98)00009-8.

Brickley, J. A., Coles, J. L., \& Jarrell, G. (1997). Leadership structure: Separating the CEO and chairman of the board. Journal of Corporate Finance, 3(3), 189-220. https://doi.org/10.1016/Sog29-1199(96)00013-2.

Brockman, P., Lee, H. S. G., \& Salas, J. M. (2016). Determinants of CEO compensation: Generalist-specialist versus insider-outsider attributes. Journal of Corporate Finance, 39, 53-77. https://doi.org/10.1016/j.jcorpfin. 2016.04.007. 
Burke, M. J., \& Day, R. R. (1986). A cumulative study of the effectiveness of managerial training. Journal of Applied Psychology, 71(2), 232. https://doi.org/10.1037/0021-9010.71.2.232.

Cai, Y., Jo, H. \& Pan, C. (2011). Vice or virtue? The impact of corporate social responsibility on executive compensation. Journal of Business Ethics, 104(2), 159-173. https://doi.org/10.1007/s10551011-0909-7.

Caselli, F., Esquivel, G., \& Lefort, F. (1996). Reopening the convergence debate: A new look at cross-country growth empirics. Journal of Economic Growth, 1(3), 363-389. https://doi.org/10.1007/BFo0141044

Chakravarthy, B. S. (1986). Measuring strategic performance. Strategic Management Journal, 7(5), 437-458. https://doi.org/10.1002/smj.4250070505.

Chan, M. C., Watson, J., \& Woodliff, D. (2014). Corporate governance quality and CSR disclosures. Journal of Business Ethics, 125(1), 59-73. https://doi.org/10.1007/s10551-013-1887-8.

Clarkson, M. B. E. (1995). A stakeholder framework for analyzing and evaluating corporate social performance. The Academy of Management Review, 20(1), 92-117. https://doi.org/10.2307/258888

Core, J. E., Holthausen, R. W., \& Larcker, D. F. (1999). Corporate governance, chief executive officer compensation, and firm performance. Journal of Financial Economics, 51(3), 371-406. https://doi.org/ 10.1016/S0304-405X(98)00058-0.

Cowen, S. S., Ferreri, L. B., \& Parker, L. D. (1987). The impact of corporate characteristics on social responsibility disclosure: A typology and frequency-based analysis. Accounting, Organizations and Society, 12(2), 111-122. https://doi.org/10.1016/0361-3682(87)90001-8.

Eccles, R. G., Serafeim, G., \& Krzus, M. P. (2011). Market interest in nonfinancial information. Journal of Applied Corporate Finance, 23(4), 113-127. https://doi.org/10.1111/j.1745-6622.2011.00357.x.

ET Bureau. (2019). CEO pay formula: More risk, more gain. https://www.google.com/amp/s/m.economictimes. com/jobs/ceo-pay-formula-more-risk-more-gain/amp_articleshow/70867955.cms/ (Accessed 15 August 2020).

ET Prime. (2019). Altico faces RBI ire for showering CEO with INR 10 crore even as lenders knock on the door. https://prime.economictimes.indiatimes.com/news/72132850/corporate-governance/altico-faces-rbi-irefor-showering-ceo-with-inr10-crore-even-as-lenders-knock-on-the-door/ (Accessed 27 November 2019).

Freeman, R. E. (1984). Strategic management: A stakeholder approach. Cambridge University Press. https://doi.org/10.1017/CBO9781139192675.

Gao, L., \& Zhang, J. H. (2013). Firms' earnings smoothing, corporate social responsibilities, and valuation. Journal of Corporate Finance, 32, 108-127. https://doi.org/10.1016/j.jcorpfin.2015.03.004.

Ghosh, A. (2003). Board Structure, Executive Compensation and Firm Performance in Emerging Economies: Evidence from India. Indira Gandhi Institute of Development Research Working Paper, 91-9819090266.

Ghosh, A. (2006a). Determination of executive compensation in an emerging economy. Evidence from India. Emerging Markets Finance and Trade, 42(3), 66-90. https://doi.org/10.2753/REE1540-496X420304.

Ghosh, S. (2006b). Do board characteristics affect corporate performance? Firm-level evidence for India. Applied Economics Letters, 13(7), 435-443. https://doi.org/10.1080/13504850500398617.

Hall, B. J., \& Liebman, J. B. (1998). Are CEOs really paid like bureaucrats? The Quarterly Journal of Economics, 113(3), 653-691. https://doi.org/10.1162/003355398555702.

J.P. Morgan. (2020). Why COVID-19 could prove to be a major turning point for ESG investing. https://www. jpmorgan.com/global/research/covid-19-esg-investing/ (Accessed 15 August 2020).

Jadiyappa, N., Jyothi, P., Sireesha, B., \& Hickman, L. E. (2019). CEO Gender, firm performance and agency costs: Evidence from India. Journal of Economic Studies, 46(2), 482-495. https://doi.org/10.1108/ JES-08-2017-0238.

Jaiswall, S. S. K., \& Bhattacharyya, A. K. (2016). Corporate governance and CEO compensation in Indian firms. Journal of Contemporary Accounting \& Economics, 12(2), 159-175. https://doi.org/10.1016/j.jcae.2016. 06.001.

Jaiswall, M., \& Firth, M. (2009). CEO pay, firm performance, and corporate governance in India's listed firms. International Journal of Corporate Governance, 1(3), 227-240. https://doi.org/10.1504/IJCG.2009.029367. 
Jensen, M. C. (1986). Agency costs of free cash flow, corporate finance, and takeovers. The American Economic Review, 76(2), 323-329.

Jensen, M. C., \& Murphy, K. J. (1990). CEO incentives: It's not how much you pay, but how. Journal of Applied Corporate Finance, 22(1), 64-76. https://doi.org/10.1111/j.1745-6622.2010.00262.x.

Jian, M., \& Lee, K. W. (2015). CEO compensation and corporate social responsibility. Journal of Multinational Financial Management, 29, 46-65. https://doi.org/10.1016/j.mulfin.2014.11.004.

Jizi, M. I., Salama, A., Dixon, R., \& Stratling, R. (2014). Corporate governance and corporate social responsibility disclosure: Evidence from the US banking sector. Journal of Business Ethics, 125(4), 601-615. https://doi.org/10.1007/s10551-013-1929-2.

Jo, H., \& Harjoto, M. A. (2011). Corporate governance and firm value: The impact of corporate social responsibility. Journal of Business Ethics, 103(3), 351-383. https://doi.org/10.1007/s10551-0110869-y.

John, T. A., \& John, K. (1993). Top-management compensation and capital structure. The Journal of Finance, 48(3), 949-974. https://doi.org/10.1111/j.1540-6261.1993.tbo4026.x.

Karim, K., Lee, E., \& Suh, S. (2018). Corporate social responsibility and CEO compensation structure. Advances in Accounting, 40, 27-41. https://doi.org/10.1016/j.adiac.2017.11.002.

Khan, M. (2019). Corporate governance, ESG, and stock returns around the world. Financial Analysts Journal, 75(4), 103-123. https://doi.org/10.1080/0015198X.2019.1654299.

Khan, W. A., \& Vieito, J. P. (2013). CEO gender and firm performance. Journal of Economics and Business, 67, 55-66. https://doi.org/10.1016/j.jeconbus.2013.01.003.

Khanna, T., \& Palepu, K. (2000). Is group affiliation profitable in emerging markets? An analysis of diversified Indian business groups. The Journal of Finance, 55(2), 867-891. https://doi.org/10.1111/ 0022-1082.00229.

Lewellen, W., Loderer, C., \& Martin, K. (1987). Executive compensation and executive incentive problems. Journal of Accounting and Economics, 9(3), 287-310. https://doi.org/10.1016/0165-4101(87) 90009-7.

Li, F., Li, T., \& Minor, D. (2016). CEO power, corporate social responsibility, and firm value: A test of agency theory. International Journal of Managerial Finance, 12(5), 611-628. https://doi.org/10.1108/IJMF-052015-0116.

Lilling, M. S. (2006). The link between CEO compensation and firm performance: Does simultaneity matter? Atlantic Economic Journal, 34(1), 101-114. https://doi.org/10.1007/s11293-006-6132-8.

Liu, C. (2018). Are women greener? Corporate gender diversity and environmental violations. Journal of Corporate Finance, 52, 118-142. https://doi.org/10.1016/j.jcorpfin.2018.08.004.

Malik, F., Wang, F., Naseem, M. A., Ikram, A., \& Ali, S. (2020). Determinants of corporate social responsibility related to CEO attributes: An empirical study. SageOpen, 10(1), 1-12. https://doi.org/10.1177/ 2158244019899093.

McWilliams, A., \& Siegel, D. (2001). Corporate social responsibility: A theory of the firm perspective. Academy of Management Review, 26(1), 117-127. https://doi.org/10.5465/AMR.2001.4011987.

Mehran, H. (1995). Executive compensation structure, ownership, and firm performance. Journal of Financial Economics, 38(2), 163-184. https://doi.org/10.1016/0304-405X(94)00809-F.

Milbourn, T. T. (2003). CEO reputation and stock-based compensation. Journal of Financial Economics, 68(2), 233-262. https://doi.org/10.1016/S0304-405X(03)00066-7.

Miles, P. C., \& Miles, G. (2013). Corporate social responsibility and executive compensation: Exploring the link. Social Responsibility Journal, 9(1), 76-90. https://doi.org/10.1108/17471111311307822.

Mishra, R., \& Kapil, S. (2017). Effect of board characteristics on firm value: Evidence from India. South Asian Journal of Business Studies, 7(1), 41-72. https://doi.org/10.1108/SAJBS-08-2016-0073.

Mishra, S., \& Modi, S. B. (2013). Positive and negative corporate social responsibility, financial leverage, and idiosyncratic risk. Journal of Business Ethics, 117(2), 431-448. https://doi.org/10.1007/ s10551-012-1526-9. 
Moneycontrol Contributer. (2019). Indian CEO pay has outpaced company performance in the past five years. https://www.moneycontrol.com/news/business/companies/indian-ceo-pay-has-outpaced-companyperformance-in-the-past-five-years-3725691/ (Accessed 13 December 2019).

Mukhtaruddin, M., Ubaidillah, U., Dewi, K., Hakiki, A., \& Nopriyanto, N. (2019). Good corporate governance, corporate social responsibility, firm value, and financial performance as moderating variable. Indonesian Journal of Sustainability Accounting and Management, 3(1), 55-64. https://doi.org/10.28992/ ijsam.v3i1.74.

Murphy, K. J. (1999). Executive compensation. In O.C. Ashenfelter \& D. Card (Eds), Handbook of labor economics (Vol. 3(Part B), pp. 2485-2563). Elsevier,. https://doi.org/10.1016/S1573-4463(99)30024-9.

Murphy, K. J., \& Zabojnik, J. (2004). CEO pay and appointments: A market-based explanation for recent trends. American Economic Review, 94(2), 192-196. https://doi.org/10.1257/0002828041302262.

Narayanaswamy, R., Raghunandan, K., \& Rama, D. V. (2012). Corporate governance in the Indian context. Accounting Horizons, 26(3), 583-599. https://doi.org/10.2308/acch-50179.

Oxfam India. (2018). India inequality report-widening gaps. https://www.oxfamindia.org/sites/default/files/ WideningGaps_IndialnequalityReport2018.pdf/ (Accessed 07 January 2020).

Patnaik, P., \& Suar, D. (2020). Does corporate governance affect CEO compensation in Indian manufacturing firms? Journal of Public Affairs, 20(3), e2115. https://doi.org/10.1002/pa.2115.

Raithatha, M., \& Komera, S. (2016). Executive compensation and firm performance: Evidence from Indian firms. IIMB Management Review, 28(3), 160-169. https://doi.org/10.1016/j.iimb.2016.07.002.

Rekker, S. A., Benson, K. L., \& Faff, R. W. (2014). Corporate social responsibility and CEO compensation revisited: Do disaggregation, market stress, gender matter? Journal of Economics and Business, 72, 84-103. https://doi.org/10.1016/j.jeconbus.2013.11.001.

Roberts, R. W. (1992). Determinants of corporate social responsibility disclosure: An application of stakeholder theory. Accounting, Organizations and Society, 17(6), 595-612. https://doi.org/10.1016/0361-3682(92) 90015-K.

Ronald, S., Ng, S., \& Daromes, F. E. (2019). Corporate social responsibility as economic mechanism for creating firm value. Indonesian Journal of Sustainability Accounting and Management, 3(1), 22-36. https://doi.org/ 10.28992/ijsam.v3i1.69.

Roodman, D. (2009). How to do xtabond2: An Introduction to difference and system GMM in Stata. The Stata Journal, 9(1), 86-136. https://doi.org/10.1177\%2F1536867Xo900900106.

Ross, S. A. (1977). The determination of financial structure: The incentive signaling approach. Bell Journal of Economics, 8(1), 23-40. https://doi.org/10.2307/3003485

Sheikh, M. F., Shah, S. Z. A., \& Akbar, S. (2018). Firm performance, corporate governance and executive compensation in Pakistan. Applied Economics, 50(18), 2012-2027. https://doi.org/10.1080/00036846.2017. 1386277.

Spicer, B. H. (1978). Investors, corporate social performance and information disclosure: An empirical study. Accounting Review, 53(1), 94-111.

Suteja, J., Gunardi, A., \& Auristi, R. J. (2017). Does corporate social responsibility shape the relationship between corporate governance and financial performance?. Indonesian Journal of Sustainability Accounting and Management, 1(2), 59-68. https://doi.org/10.28992/ijsam.v1i1.33.

Tamimi, N., \& Sebastianelli, R. (2017). Transparency among S\&P 500 companies: An analysis of ESG disclosure scores. Management Decision, 55(8), 1660-1680. https://doi.org/10.1108/MD-01-2017-0018.

Tomar, A., \& Korla, S. (2011). Global recession and determinants of CEO compensation: An empirical investigation of listed Indian firms. Indore Management Journal, 3(2), 11-26.

Waddock, S. A., \& Graves, S. B. (1997). The corporate social performance-financial performance link. Strategic Management Journal, 18(4), 303-319. https://doi.org/10.1002/(SICI)1097-0266(199704)18:4\%3C303::AIDSMJ869\%3E3.0.CO;2-G.

Yu, E. P. Y., Guo, C. Q., \& Luu, B. V. (2018). Environmental, social and governance transparency and firm value. Business Strategy and the Environment, 27(7), 987-1004. https://doi.org/10.1002/bse.2047. 


\section{APPENDIX}

\section{Appendix 1: List of ESG Companies}

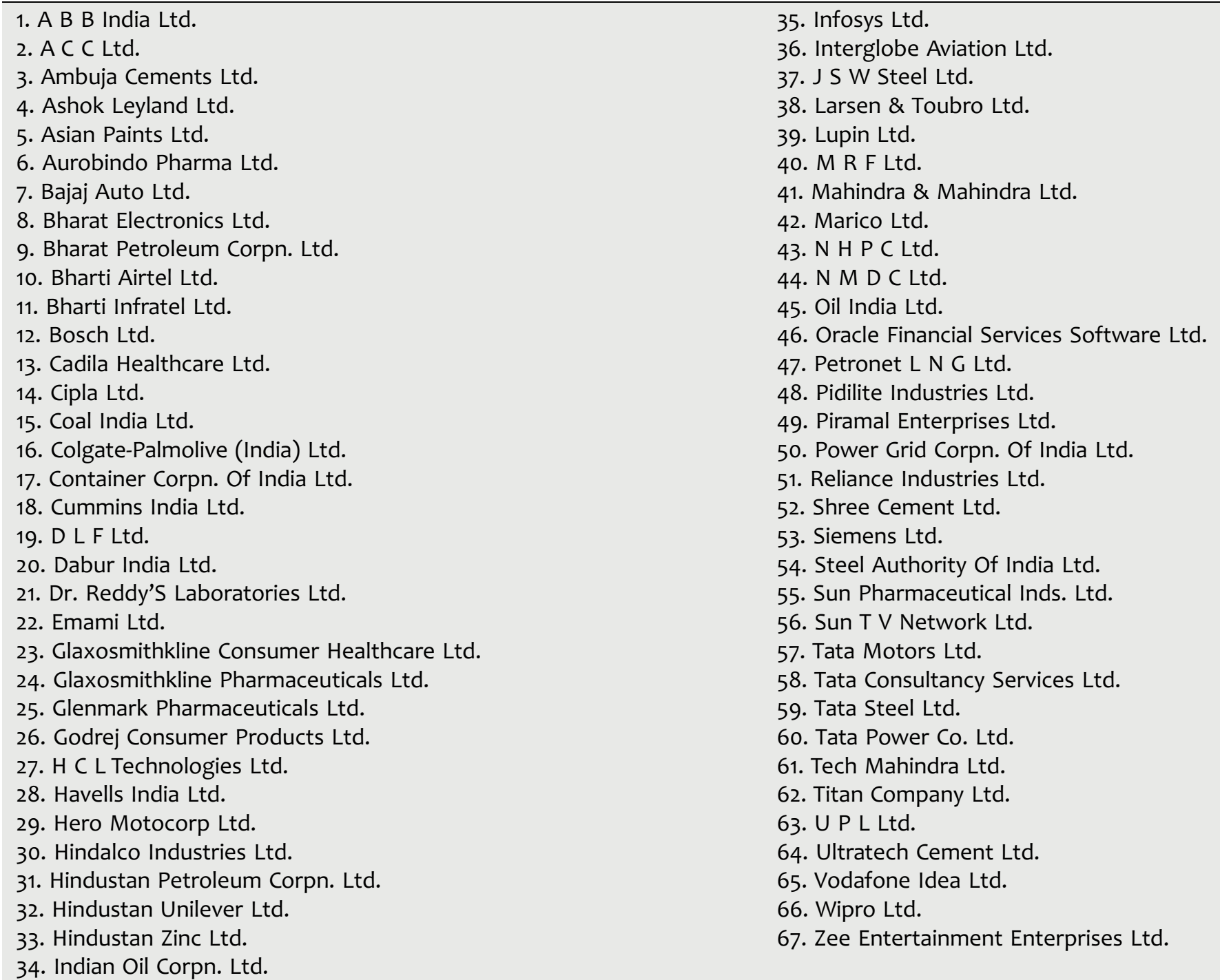

Note: Data extracted from CMIE Prowess database NSE Nifty 100 ESG Index 